\title{
Strength Characteristics of Low Calcium Fly Ash Based Geopolymer Concrete.
}

\author{
Chandan Kumar ${ }^{1}$, Krishna Murari ${ }^{2}$, C.R.Sharma ${ }^{2}$. \\ 1. M.Tech student, Dept of civil engineering, B.I.T Sindri, Dhanbad (India). \\ 2. Asst. Prof. Dept of civil engineering, B.I.T Sindri, Dhanbad (India).
}

\begin{abstract}
Portland cement concrete industry has grown astronomically in recent years. It will continue to grow as the result of continuous urban development. However, Portland cement concrete posses problems such as durability and carbon dioxide emission. Many concrete structures have shown serious deterioration, way before their intended service life, especially those constructed in a corrosive environment (Mehta 1997).

Geopolymer is a class of aluminosilicate binding materials synthesized by thermal activation of solid aluminosilicate base materials such as fly ash, metakaolin, GGBS etc., with an alkali metal hydroxide and silicate solution. These binders are currently attracting widespread attention due to their potential utilization as a high performance, environmental friendly and sustainable alternative to Portland cement

India being the largest coal fly-ash producer in the world produces abundant by- product from thermal power plant known as coal fuel ash

Based on the mixture design process eighty one test cubes of 150x150x150mm of low-calcium fly ash-based geopolymer concrete were cast to study the effect of various parameters on compressive strength of low-calcium fly ash-based geopolymer concrete.
\end{abstract}

Keywords: - Geopolymer concrete, Characteristic strength, Fly ash, Superplasticizer.

\subsection{GENERAL}

\section{INTRODUCTION}

Concrete usage around the world is second only to water. Ordinary Portland cement (OPC) is conventionally used as the primary binder to produce concrete. The environmental issues associated with the production of OPC are well known. The amount of the carbon dioxide released during the manufacture of OPC due to the calcination of limestone and combustion of fossil fuel is in the order of one ton for every ton of OPC produced. In addition, the extent of energy required to produce OPC is only next to steel and aluminum.

On the other hand, the abundant availability of fly ash worldwide creates opportunity to utilize this by-product of burning coal, as a substitute for OPC to manufacture concrete. When used as a partial replacement of OPC, in the presence of water and in ambient temperature, fly ash reacts with the calcium hydroxide during the hydration process of OPC to form the calcium silicate hydrate (C-S-H) gel.

In 1978, Davidovits (1999) proposed that binders could be produced by a polymeric reaction of alkaline liquids with the silicon and the aluminium in source materials of geological origin or by-product materials such as fly ash and rice husk ash. He termed these binders as geopolymers. Palomo et al (1999) suggested that pozzolans such as blast furnace slag might be activated using alkaline liquids to form a binder and hence totally replace the use of OPC in concrete.

In this work, low-calcium fly ash-based geopolymer is used as the binder, instead of Portland or other hydraulic cement paste, to produce concrete. The fly ash-based geopolymer paste binds the loose coarse aggregates, fine aggregates and other un-reacted materials together to form the geopolymer concrete, with or without the presence of admixtures. The manufacture of geopolymer concrete is carried out using the usual concrete technology methods.

\subsection{FLY ASH INDUCED CONCRETE}

Out of various cementing materials, Fly ash is the most widely used material worldwide. Fly ash is by product from the combustion of pulverized coal in thermal power plants. Fly ash, if not utilized has to be disposed of in landfills, ponds or rejected in river systems, which may present serious environmental concerns since it is produced in large volumes. This is particularly an important issue for India, which currently produces over 100 million ton of fly ash annually.

A concerted effort is required for the concrete producers \& end users to take a pro-active approach to find optimum utilization areas for supplementary cementing materials, which will enhance the concrete product and efficiently utilize its properties. 
The use of fly ash in concrete in optimum proportion has many technical benefits and improves concrete performance in both fresh and hardened state. Fly ash use in concrete improves the workability of plastic concrete, and the strength and durability of hardened concrete. Generally, fly ash benefits concrete by reducing the mixing water requirement and improving the paste flow behavior.

- The decrease in water content combined with the production of additional cementitious compounds reduces the pore interconnectivity of concrete, thus increasing durability and resistance to various forms of deterioration.

- The decrease in free lime and resulting increase in cementitious compounds, combined with the reduction in permeability enhance concrete durability. This brings several associated technical benefits, such as resistance to alkali-silica reaction and resistance to sulphate reaction

- Improved resistance to alkali silica reaction is achieved as fly ash reacts with available alkali in the concrete which makes them less available to react with certain silica minerals contained in the aggregates

- Fly ash concrete is more durable than asphalted concrete and needs almost no maintenance.

- The design of a highway pavement is based on flexural strength and fly ash concrete continues gaining strength with age.

- More paste volume and lesser bleeding and segregation of concrete mix during placing and compaction leads to better finishing and texturing.

- Higher compressive strength results over period of time as fly ash continues to combine with free lime.

- Fly ash enhances the density of matrix thus increases the points of contact, causing increase in tensile strength, consequently the flexural strength, which is the design criterion for pavement quality concrete.

- The lubricating action of fly ash reduces water content and hence drying shrinkage.

- The pozzolanic activity between fly ash and lime generate less heat resulting in reduced thermal cracking when fly ash is used to replace Portland cement.

There is no doubt that the reduced use of natural resources and recycling of used and waste materials are the key elements in sustainable development but this is not just sufficient.

\subsection{GEOPOLYMER MATERIAL}

Geopolymers are inorganic polymeric binding materials. Joseph Davidovits, coined the term "geopolymer" in 1978 to classify the newly discovered geosynthesis that produces inorganic polymeric materials.

The chemical composition of the geopolymer material is similar to natural zeolitic materials, but the microstructure is amorphous. Geopolymer material with sodium hydroxide and cured at elevated temperature will attributed more stable cross- linked alumino silicate polymer structure. The properties and uses of geopolymers are being explored in many scientific and industrial disciplines.

\subsection{METHODOLOGY}

The methodology for the present work will consists of following steps

- To develop geopolymer concrete using fly ash as a source material

- To develop the process of mixing with optimized use of alkaline activators like sodium hydroxide and sodium silicate.

- Setting up of curing regimens applied to the geopolymers concrete to study the effect on the rest period before heat curing.

- To observe the fresh and hardened properties of fly ash-based geopolymer concrete, mainly its workability and compressive strength.

- To study the effect of super plasticizer on low calcium fly ash based geopolymer concrete.

\section{EXPERIMENTAL PROGRAM}

1.1 Materials

The material used in present investigation were locally available in Sindri, Dist- Dhanbad(Jharkhand) and physical properties were found through various laboratory tests conducted in Concrete and Road material lab, B.I.T Sindri.

\subsubsection{Fine aggregate}

Ordinary sand available in Sindri, Dhanbad

(Damodar river sand) having the following characteristics has been used.

Specific gravity $\quad: 2.67$

Fineness modulus : 2.60

Unit weight $\quad: 1.674 \mathrm{gm} / \mathrm{cc}$

Water absorption : $0.44 \%$

Bulking : $25 \%$ 
Sand after sieve analysis (Table 2.1) confirm to zone - II as per IS 383-1970.

Table 2.1 Sieve analysis of fine aggregate

\begin{tabular}{|c|c|c|c|c|c|}
\hline $\begin{array}{c}\text { IS Sieve } \\
(\mathrm{mm})\end{array}$ & $\begin{array}{l}\text { Wt.R } \\
\text { etaine } \\
\mathrm{d} \\
(\mathrm{Kg})\end{array}$ & $\begin{array}{l}\text { Cum. } \\
\text { Wt. } \\
(\mathrm{Kg})\end{array}$ & $\begin{array}{c}\% \\
\text { Retain } \\
\text { ed }\end{array}$ & $\begin{array}{c}\% \\
\text { Passi } \\
\text { ng }\end{array}$ & $\begin{array}{l}\text { Remark } \\
\text { s }\end{array}$ \\
\hline 4.75 & 0.034 & 0.034 & 3.4 & 96.6 & \multirow{5}{*}{$\begin{array}{c}\text { Sand } \\
\text { Zone II } \\
\text { As per } \\
\text { IS: } \\
383- \\
1970\end{array}$} \\
\hline 2.36 & 0.026 & 0.060 & 6 & 94 & \\
\hline 1.18 & 0.140 & 0.200 & 20 & 80 & \\
\hline 600 & 0.162 & 0.362 & 36.2 & 63.3 & \\
\hline 300 & 0.425 & 0.787 & 78.7 & 21.3 & \\
\hline 150 & 0.185 & 0.972 & 97.2 & 2.30 & $\begin{array}{c}\text { CLAUS } \\
\text { E } 4.3 \\
\text { TABLE } \\
4\end{array}$ \\
\hline
\end{tabular}

1.1.2 Coarse aggregate

Locally available black crushed stone (Pakur stone) in Sindri with maximum nominal size of $20 \mathrm{~mm}$ and $10 \mathrm{~mm}$ have been used as coarse aggregate. The physical properties for the coarse aggregate as found through laboratory test according to IS 2386-1963 is resulted as:

$$
\begin{array}{ll}
\text { Aggregate crushing value } & =24 \% \\
\text { Aggregate impact value } & =29 \% \\
\text { Specific gravity } & =2.74 \\
\text { Water absorption } & =0.94 \% \\
\text { Unit weight } & =1.60 \mathrm{gm} / \mathrm{cc} \\
\text { Fineness Modulus } & =6.15
\end{array}
$$

\begin{tabular}{|c|c|c|c|c|c|}
\hline $\begin{array}{c}\text { Sieve } \\
\text { size } \\
(\mathrm{mm})\end{array}$ & $\begin{array}{c}\text { Weight } \\
\text { retaine } \\
\mathrm{d} \\
(\mathrm{Kg})\end{array}$ & $\begin{array}{l}\text { Cum } \\
\text {.wt } \\
(\mathrm{Kg})\end{array}$ & $\begin{array}{c}\text { Percen } \\
\mathrm{t} \\
\text { retaine } \\
\mathrm{d}\end{array}$ & $\begin{array}{l}\text { Percent } \\
\text { age } \\
\text { passing }\end{array}$ & $\begin{array}{c}\text { Rem } \\
\text { arks }\end{array}$ \\
\hline 40 & 0.000 & $\begin{array}{c}0.00 \\
0\end{array}$ & 0 & 100 & \multirow{5}{*}{$40 \%$} \\
\hline 20 & 0.000 & $\begin{array}{c}0.00 \\
0\end{array}$ & 0 & 100 & \\
\hline 12.5 & 0.000 & $\begin{array}{c}0.00 \\
0\end{array}$ & 0 & 100 & \\
\hline 10 & 1.400 & 1.40 & 28.00 & 72 & \\
\hline 4.75 & 3.304 & $\begin{array}{c}4.70 \\
4\end{array}$ & 94.08 & 5.92 & \\
\hline
\end{tabular}

Sieve analysis of the locally available coarse aggregate is given in Table 2.2 and 2.3.

Table 2.2 Sieve analysis of coarse aggregate $20 \mathrm{~mm}$

\begin{tabular}{|c|c|c|c|c|c|}
\hline $\begin{array}{c}\text { Sieve size } \\
(\mathrm{mm})\end{array}$ & $\begin{array}{c}\text { Weight } \\
\text { retained }(\mathrm{Kg})\end{array}$ & $\begin{array}{c}\text { Cum.wt } \\
(\mathrm{Kg})\end{array}$ & $\begin{array}{c}\text { Percent } \\
\text { retained }\end{array}$ & $\begin{array}{c}\text { Percentage } \\
\text { passing }\end{array}$ & $\begin{array}{c}\text { Rem } \\
\text { arks }\end{array}$ \\
\hline 40 & 0.000 & 0.000 & 0 & 100 & \\
\hline 20 & 0.470 & 0.470 & 9.4 & 90.6 & \\
\hline 12.5 & 3.461 & 3.931 & 78.62 & 21.38 & \multirow{2}{*}{$60 \%$} \\
\hline 10 & 0.463 & 4.393 & 87.88 & 12.12 & \\
\hline 4.75 & 0.562 & 4.956 & 99.12 & 0.88 & \\
\hline
\end{tabular}

Table 2.3 Sieve analysis of coarse aggregate $10 \mathrm{~mm}$ 


\subsubsection{Flyash}

Fine low calcium fly ash samples taken from Bokaro Thermal Power Station, Bokaro (Jharkhand) were used in this study. This fly ash was of average quality formed with the combustion of lignite and bituminous coal. The colour of the fly ash was light grey. The sample satisfied the requirements of IS 3812(Part I).

The chemical characteristics are presented in table 2.4. The chemical property of the fly ash has been presumed based on the data made available from Bokaro Thermal Power Station, Bokaro (Jharkhand).

Table 2.4 Chemical Properties of Fly Ash

\begin{tabular}{|c|l|c|c|}
\hline $\begin{array}{c}\text { Sl. } \\
\text { No. }\end{array}$ & $\begin{array}{l}\text { Test } \\
\text { Conducted }\end{array}$ & $\begin{array}{c}\text { Observed } \\
\text { Values } \\
(\%)\end{array}$ & $\begin{array}{c}\text { Requirement as } \\
\text { per IS:1320- } \\
\mathbf{1 9 8 1}\end{array}$ \\
\hline 1 & $\begin{array}{l}\text { Loss of } \\
\text { Ignition }\end{array}$ & 2.32 & $5.0(\max )$ \\
\hline 2 & $\begin{array}{l}\mathrm{Silica}^{2} \text { as } \\
\mathrm{SiO}_{2}\end{array}$ & 42.04 & $\begin{array}{c}\mathrm{SiO}_{2}+\mathrm{Fe}_{2} \mathrm{O}_{3}+ \\
\mathrm{Al}_{2} \mathrm{O}_{3}=70\end{array}$ \\
\hline 3 & $\begin{array}{l}\text { Iron as } \\
\mathrm{Fe}_{2} \mathrm{O}_{3}\end{array}$ & 4.40 & - \\
\hline 4 & $\begin{array}{l}\text { Alumina as } \\
\mathrm{Al}_{2} \mathrm{O}_{3}\end{array}$ & 33.60 & - \\
\hline 5 & $\begin{array}{l}\mathrm{Calcium} \text { as } \\
\mathrm{CaO}\end{array}$ & 12.73 & - \\
\hline 6 & $\begin{array}{l}\text { Magnesium } \\
\text { as MgO }\end{array}$ & 0.00 & 5.0 \\
\hline 7 & $\begin{array}{l}\text { Sulphate as } \\
\text { SO }\end{array}$ & 0.40 & 3.0 \\
\hline 8 & $\mathrm{Chloride}_{3}$ & - & \multicolumn{2}{|l|}{} \\
\hline 9 & $\begin{array}{l}\text { Lime } \\
\text { Reactivity }\end{array}$ & 4.00 & 4.5 \\
\hline
\end{tabular}

\subsubsection{Chemical Solution}

A combination of sodium silicate solution and sodium hydroxide solution was chosen as the alkaline liquid. Sodium-based solutions were chosen because they were cheaper than Potassium-based solutions. Both were commercially available in market.

\section{SODIUM HYDROXIDE}

The sodium hydroxide $(\mathrm{NaOH})$ solution was prepared by dissolving the pellets in water. The mass of $\mathrm{NaOH}$ solids in a solution varied depending on the concentration of the solution expressed in terms of molar, $\mathrm{M}$. For instance, $\mathrm{NaOH}$ solution with a concentration of $8 \mathrm{M}$ consisted of $8 \mathrm{x} 40=320$ grams of $\mathrm{NaOH}$ solids (in flake or pellet form) per litre of the solution, where 40 is the molecular weight of $\mathrm{NaOH}$. The mass of $\mathrm{NaOH}$ solids for $97 \%$ purity was measured as 260 grams per $\mathrm{kg}$ of $\mathrm{NaOH}$ solution of $8 \mathrm{M}$ concentration. Similarly, the mass of $\mathrm{NaOH}$ solids per $\mathrm{kg}$ of the solution for other concentrations were measured as $10 \mathrm{M}$ : 314 grams, $12 \mathrm{M}$ : 361 grams, 14M: 404 grams, and 16M: 444 grams. Note that the mass of $\mathrm{NaOH}$ solids was only a fraction of the mass of the $\mathrm{NaOH}$ solution, and water is the major component. The above calculations are tabulated in table 2.5

Table 2.5 Mass of $\mathrm{NaOH}$ Solids Per $1000 \mathrm{gm}$ of $\mathrm{NaOH}$ solution with $97 \%$ purity

\begin{tabular}{|c|c|}
\hline MOLARITY & MASS OF NaOH Solids(gm) \\
\hline $8 \mathrm{M}$ & 260 \\
\hline $10 \mathrm{M}$ & 314 \\
\hline $12 \mathrm{M}$ & 361 \\
\hline $14 \mathrm{M}$ & 404 \\
\hline $16 \mathrm{M}$ & 444 \\
\hline
\end{tabular}

Further, through literature review it was strongly recommended that the sodium hydroxide solution must be prepared 24 hours prior to use as it terminates to semi solid liquid state after 36 hours. The same recommendation was adopted in the present work. 


\section{SODIUM SILICATE}

Sodium Silicate was available in semisolid form. The sodium silicate solution $(\mathrm{Na} 2 \mathrm{O}=14.7 \%, \mathrm{SiO} 2=29.4 \%$, and water $=55.9 \%$ by mass) was purchased from a local supplier in bulk.

\section{SUPER PLASTICISER}

Out of the large number of admixtures used in concrete to obtain improve performance characteristics, the admixtures which have significant effect on the rheology of concrete are plasticizers and super-plasticizers, airentraining agents, accelerators and retarders. These admixtures are used in three ways:

(i) To give increased workability with the same long-term strength and durability,

(ii) To give same workability with less water content and hence higher strength, and

(iii) To give the same workability and strength with less cement content; however, the reduced cement content

should be enough from durability consideration.

To improve the workability of the fresh geopolymer concrete, a naphthalene sulphonate super plasticizer was used in most of the mixtures.

Another type of super plasticiser, a polycarboxylic ether hyperplasticiser, under the brand name of Apex La Greens was also tried.

\subsubsection{Water}

Distilled water was used throughout the test procedure to achieve exact molarity.

1.2 Mix design of Geopolymer Concrete

As in the case of Portland cement concrete, the coarse aggregates and fine aggregates occupy about $75 \%-80 \%$ mass of Geopolymer concrete. Assuming the aggregates to be in surface saturated dry condition and the unit weight of concrete is $2400 \mathrm{Kg} / \mathrm{m}^{3}$. Combined aggregates are assumed to consist of $70 \%$ coarse aggregate and $30 \%$ fine aggregate.

Mass of combined aggregate $=76 \%$ of $2400 \mathrm{Kg} / \mathrm{m}^{3}$

$$
=1824 \mathrm{Kg} / \mathrm{m}^{3}
$$

Mass of coarse aggregate $=70 \%$ of $1824 \mathrm{Kg} / \mathrm{m}^{3}$

Mass of fine aggregate $=30 \%$ of $1824 \mathrm{Kg} / \mathrm{m}^{3}$

Mass of low-calcium fly ash and alkaline liquid

Alkaline solution/ Fly ash ratio $=0.35$

Fly ash content $=576 /(1+0.35)=427 \mathrm{Kg} / \mathrm{m}^{3}$

Alkaline solution $=0.35 \times 427=149 \mathrm{Kg} / \mathrm{m}^{3}$

$\left(\mathrm{Na}_{2} \mathrm{SiO}_{3} / \mathrm{NaOH}\right)_{\text {solution }}$ by mass $=2.5$

$\mathrm{NaOH}$ solution $=149 / 3.5=42.57 \mathrm{Kg} / \mathrm{m}^{3}$

$\mathrm{Na}_{2} \mathrm{SiO}_{3}$ solution $=149-42.57=106.43 \mathrm{Kg} / \mathrm{m}^{3}$

In commercially available $\mathrm{Na} 2 \mathrm{SiO} 3$ solution we have:-

$\mathrm{SiO}_{2} / \mathrm{Na}_{2} \mathrm{O}=2 \quad \mathrm{Na}_{2} \mathrm{O}=14.7 \% \quad \mathrm{SiO}_{2}=29.4 \% \quad$ Water $=55.9 \%$

Therefore in $\mathrm{Na}_{2} \mathrm{SiO}_{3}$ Solution

$\mathrm{Na}_{2} \mathrm{SiO}_{3}$ solids $=0.441 \times 106.43=46.93 \mathrm{Kg} / \mathrm{m}^{3}$

Water content $=0.559 \times 106.43=59.49 \mathrm{Kg} / \mathrm{m}^{3}$

$\mathrm{Na}_{2} \mathrm{O}$ content $=0.147 \times 106.43=15.64 \mathrm{Kg} / \mathrm{m}^{3}$

$\mathrm{SiO}_{2}$ content $=29.4 \%$ of $106.43=31.29 \mathrm{Kg} / \mathrm{m}^{3}$

From the chemical characteristics of fly ash (table 2.4) the $\mathrm{SiO}_{2}$ content in the Fly ash is $42.04 \%$ therefore Total $\mathrm{SiO}_{2}$ content in the Mix $=31.29+42.04 \%$ of $427=31.29+179.51=210.80 \mathrm{Kg} / \mathrm{m}^{3}$

\section{CALCULATION FOR 8M NAOH SOLUTION:-}

In 1000 grams of $8 \mathrm{M} \mathrm{NaOH}$ solution it is found that 260 grams of $\mathrm{NaOH}$ solids are present and the rest mass is governed by water as main constituent.

Weight of $\mathrm{NaOH}$ solids in the solution $=26 \%$ of $42.57 \mathrm{Kg} / \mathrm{m}^{3}=11.07 \mathrm{Kg} / \mathrm{m}^{3}$

Weight of Water in $\mathrm{NaOH}$ solution $=74 \%$ of $42.57 \mathrm{Kg} / \mathrm{m}^{3}=31.5 \mathrm{Kg} / \mathrm{m}^{3}$

Total Water content in the mix is equal to the sum of water content in $\mathrm{Na}_{2} \mathrm{SiO}_{3}$ and in $\mathrm{NaOH}$.

Therefore, Total water content $=59.5+31.5=91.0 \mathrm{Kg} / \mathrm{m}^{3}$

Total geopolymer solids $=$ weight of Fly ash + weight of $\mathrm{Na}_{2} \mathrm{SiO}_{3}+$ Weight of $\mathrm{NaOH}$ solids

$=427+46.93+11.07=485 \mathrm{Kg} / \mathrm{m}^{3}$

Total water/Geopolymer solids $=91.0 / 485$ 
$=0.1876$

Similar calculations were done for $10 \mathrm{M}, 12 \mathrm{M}, 14 \mathrm{M}$ and $16 \mathrm{M} \mathrm{NaOH}$ solution. The mix proportion is presented in table no 2.6 .

\subsection{Preliminary laboratory work}

In the beginning, numerous trial mixtures of geopolymer concrete were manufactured, and test specimens in the form of 150x150x150 mm cubes were made. Manual hand mixing is done in the concrete and road material laboratory for making geopolymer concrete. The main objectives of the preliminary laboratory work were:

- To familiarize with the making of fly ash-based geopolymer concrete;

- To understand the effect of the sequence of adding the alkaline liquid to the solids constituents in the mixture;

- To observe the behavior of the fresh fly ash-based geopolymer concrete;

- To develop the process of mixing and the curing regime; and

- To understand the basic mixture proportioning of fly ash-based geopolymer concrete.

\subsection{Mixing and casting of geopolymer concrete}

It was found that the fresh fly ash-based geopolymer concrete was dark in colour (due to the dark colour of the fly ash), and was cohesive. The amount of water in the mixture played an important role on the behaviour of fresh concrete. When the mixing time was long, mixtures with high water content bled and segregation of aggregates and the paste occurred. This phenomenon was usually followed by low compressive strength of hardened concrete.

Davidovits (2002) suggested that it is preferable to mix the sodium silicate solution and the sodium hydroxide solution together at least one day before adding the liquid to the solid constituents. He also suggested that the sodium silicate solution obtained from the market usually is in the form of a dimmer or a trimmer, instead of a monomer, and mixing it together with the sodium hydroxide solution assists the polymerization process. When this suggestion was followed, it was found that the occurrence of bleeding and segregation ceased.

From the preliminary work, it was decided to observe the following standard process of mixing in all further studies.

- Mix sodium hydroxide solution and sodium silicate solution together at least one day prior to adding the liquid to the dry materials.

- Mix all dry materials for about three minutes. Add the liquid component of the mixture at the end of dry mixing, and continue the wet mixing for another four minutes.

1.5 Curing Regimen

Preliminary tests also revealed that fly ash-based geopolymer concrete did not harden immediately at room temperature. When the room temperature was less than $30^{\circ} \mathrm{C}$, the hardening did not occur at least for 24 hours. Fly ash-based geopolymer concrete cubes were placed in universal hot oven immediately for 24 hours with mould. The moulds were removed after 24 hours and the cubes were kept at room temperature for further 24 hours after which compressive strength test was performed. The curing temperature was fixed at $40^{\circ} \mathrm{C}, 60^{\circ} \mathrm{C}$, $80^{\circ} \mathrm{C}$ and $100^{\circ} \mathrm{C}$.

\section{TESTING METODOLOGY}

1.6 Workability and Compressive strength test WORKABILITY

The workability of the fresh concrete was measured by means of the conventional slump test.

\section{COMPRESSIVE STRENGTH TEST}

The test samples of fly ash based geopolymer concrete were cast to study the compressive strength parameter. The cubes were cured in the oven at the temperature of $40^{\circ} \mathrm{C}, 60^{\circ} \mathrm{C}, 80^{\circ} \mathrm{C}$ and $100^{\circ} \mathrm{C}$ for 24 hours. The compressive strength test was done after 24 hours with universal testing machine.

\section{VII. $\quad$ EXPERIMENTAL RESULTS AND DISCUSSION}

The experimental results are presented and discussed. Each of the compressive strength test data plotted in Figures or given Tables corresponds to the mean value of the compressive strengths. The effects of salient parameters on the compressive strength of low-calcium fly ash-based geopolymer concrete are discussed. The effect of Superplasticizer on workability and strength of fly ash-based geopolymer concrete.

Finally at end discussion on indirect tensile strength and modulus of elasticity of the fly ash-based geopolymer concrete. 


\subsection{Compressive Strength test}

Compressive strength of geopolymer concrete is directly determined with the help of universal testing machine in concrete and road material laboratory, BIT Sindri. The compressive strength for different conditions is given in table 4.1 to 4.3

\subsection{Indirect tensile strength and modulus of elasticity}

Mixture 4 was used in order to measure the modulus of elasticity and tensile strength of fly ash-based geopolymer concrete. This Mixture proportion covered compressive strength range of 50MPa at four different rest period of $0,24,48$ and 72 hours .

The tensile strength of fly ash-based geopolymer concrete was calculated in accordance with the Indian Standard 456-2000. Indian standard recommends the following design expression to determine the characteristic tensile strength of OPC concrete:

$f_{c r}=0.7 \sqrt{f_{c k}}$ in $\mathrm{MPa}$

The calculated values of $\mathrm{f}_{\mathrm{cr}}$ using above equations are given in Table 4.4. These test results show that the tensile strength of geopolymer concrete is only a fraction of the compressive strength, as in the case of Portland cement concrete.

Further, the Modulus of Elasticity is primarily influenced by the elastic properties of the aggregate and to lesser by the conditions of curing and age of the concrete, the mix proportions and the type of cement. Modulus of elasticity is normally related to the compressive strength of concrete (IS: 456-2000). It can be calculated by the following equation:

$\mathrm{E}_{\mathrm{c}}=5000 \sqrt{f c k}$

Where Ec is the short term Modulus of Elasticity in $\mathrm{N} / \mathrm{mm}^{2}$. Table 4.4 also presents the value of modulus of elasticity.

\section{SUMMARY AND CONCLUSIONS}

\subsection{Summary}

The published literature contained only limited knowledge and know-how on the process of making lowcalcium (ASTM Class F) fly ash-based geopolymer concrete. Most of the literature dealt with the use of metakaolin or calcined kaolin as the source material for making geopolymer paste and mortar. Moreover, the exact details regarding the mixture compositions and the process of making geopolymers were kept undisclosed in the patent and commercially oriented research documents.

With the generic information available on geopolymer, a rigorous trial-and-error method was adopted to develop a process of manufacturing fly ash-based geopolymer concrete following the technology currently used to manufacture OPC concrete.

In order to reduce the number of variables in this trial-and-error approach, the study was restricted to lowcalcium dry fly ash obtained from BTPS, Bokaro.

After some failures in the beginning, the trail-and-error method yielded successful results with regard to manufacture of low-calcium fly ash-based geopolymer concrete. Once this was achieved, tests were performed to quantify the effect of the salient parameters that influence the short-term properties of fresh and hardened geopolymer concrete. In the following Sections, the outcomes of the study are summarized.

\subsection{Conclusions}

Based on the experimental work reported in this study, the following conclusions are drawn:

1. Higher concentration (in terms of molar) of sodium hydroxide solution results in higher compressive strength of fly ash-based geopolymer concrete (Figure 4.1).

2. Higher the ratio of sodium silicate-to-sodium hydroxide ratio by mass, higher is the compressive strength of fly ash-based geopolymer concrete

3. As the curing temperature in the range of $40^{\circ} \mathrm{C}$ to $100{ }^{\circ} \mathrm{C}$ increases, the compressive strength of fly ash-based geopolymer concrete also increases (Figure 4.2)

4. Longer curing time, in the range of 24 to 96 hours (4 days), produces higher compressive strength of fly ashbased geopolymer concrete. However, the increase in strength beyond 24 hours is not significant.

5. The Rest Period, defined as the time taken between casting of specimens and the commencement of curing, of up to 3 days increases the compressive strength of hardened fly ash-based geopolymer concrete. The increase in strength is substantial in the first 3 days of Rest Period (Figure 4.3)

6. The addition of naphthalene sulphonate-based super plasticizer, up to approximately $2 \%$ of fly ash by mass, improves the workability of the fresh fly ash-based geopolymer concrete; however, there is a nominal decrease in the compressive strength of hardened concrete when super plasticizer is used (Figure 4.5). 
7. The slump value of the fresh fly-ash-based geopolymer concrete increases with the addition of naphthalene sulphonate-based super plasticizer, up to approximately $2 \%$ of fly ash by mass (Figure 4.4)

8. The fresh fly ash-based geopolymer concrete is easily handled up to 120 minutes without any sign of setting and without any degradation in the compressive strength.

9. The indirect tensile strength of fly ash-based geopolymer concrete is a fraction of the compressive strength, as in the case of Portland cement concrete.

\section{REFRENCES}

[1]. Davidovits, J. 1984. "Pyramids of Egypt Made of Man- Made Stone, Myth or Fact?" Symposium on Archaeometry 1984. Smithsonian Institution, Washington, DC.

[2]. Davidovits, J. 2008. Geopolymer Chemistry and Applications. Institut Géopolymère, Saint-Quentin, France.

[3]. Geopolymer Institute. 2010. What Is a Geopolymer? Introduction. Institut Géopolymère, SaintQuentin, France. Accessed on January 29, 2010, at http://www.geopolymer.org/science/introduction.

[4]. Hardjito, D., S. Wallah, D. M. J. Sumajouw, and B. V. Rangan. 2004. "On the Development of Fly AshBased Geopolymer Concrete." ACI Materials Journal, vol. 101, no. 6.

[5]. Rangan, B. V.. "Low-Calcium, Fly-Ash-Based Geopolymer Concrete." Concrete Construction Engineering Handbook. Taylor and Francis Group, Boca Raton, FL, 2008.

[6]. Lloyd, N., and V. Rangan. 2009. "Geopolymer Concrete-Sustainable Cementless Concrete." ACI Special Publication SP-261, 10th ACI International Conference on Recent Advances in Concrete Technology and Sustainability Issues. American Concrete Institute, Farmington Hills, MI.

[7]. Recent Research Geopolymer Concrete- Nguyen Van Chanh Bui Dang Trung, Dang Van Tuan during the $3^{\text {rd }}$ ACF International Conference-ACF/VCA 2008.

[8]. Suresh Thokchom, Partha Ghosh and Somnath Ghos - Resistance of Fly Ash based Geopolymer Mortars in Sulfuric Acid- ARPN Journal of Engineering and Applied SciencesVOL. 4, NO. 1, FEBRUARY 2009.

[9]. D. Bondar(a), C. J. Lynsdale(b), N. B. Milestone(c), N. Hassani(d), and A. A. Ramezanianpour Engineering Properties of Alkali Activated Natural Pozzolan Concrete -Second International Conference, University of Wisconsin,June2010.

[10]. Anuar K.A, Ridzuan A.R.M., Ismail S., Universiti Teknologi MARA 40450 Shah Alam, Selangor, Malaysia, Strength Characteristic of Geopolymer Concrete - International Journal of Civil \& Environmental Engineering, Vol: 11 No: 01 February2011.

[11]. S. Vaidya and etal- Experimental evaluation of Self cure Geopolymer concrete for mass pour application - World Coal Ash Conference,2011.

[12]. Raijiwala D.B.1 Patil H. S - Geopolymer Concrete- a Concrete of next decade, Journal of Engineering Research and Studies., March 2011.

[13]. Muhd Fadhil Nuruddin, Andri Kusbiantoro, Sobia Qazi, Nasir Shafiq- Compressive Strength and Interfacial Transition Zone Characteristic of Geopolymer Concrete with Different Cast In-Situ Curing Conditions, World Academy of Science, Engineering and Technology, 2011.

[14]. Douglas C. Comrie, John H. Paterson \& Douglas J. Ritcey, D. Code Consulting Ltd, Boulevard East, Mississauga, Ontario - Applications of geopolymer technology to waste stabilization.

[15]. Thokchom S., Ghosh P. and Ghosh S., Performance of Fly ash Based Geopolymer Mortars in Sulphate Solution, Journal of Engineering Science and Technology Review 3 (1) (2010) 36-40, 24 February 2010.

[16]. Thokchom Suresh, Dr. Ghosh Partha and Dr. Ghosh Somnath, Acid Resistance of Fly ash based Geopolymer mortars, International Journal of Recent Trends in Engineering, Vol. 1, No. 6, May 2009.

[17]. Thokchom Suresh, Dr. Ghosh Partha and Dr. Ghosh Somnath, Resistance of Fly Ash based Geopolmer Mortars in Sulfuric Acid, ARPN Journal of Engineering and Applied Sciences, VOL. 4, NO. 1, FEBRUARY 2009.

\section{IMPORTANT TABLES AND FIGURES:}


Strength Characteristics of Low Calcium Fly Ash Based Geopolymer Concrete.

Table 2.6 Mix Proportion of Geopolymer Concrete

\begin{tabular}{|c|c|c|c|c|c|c|c|c|c|}
\hline \multirow{2}{*}{$\begin{array}{l}\text { Mixture } \\
\text { No. }\end{array}$} & \multirow{2}{*}{ Molarity } & \multirow{2}{*}{$\begin{array}{l}\text { Fly } \\
\text { Ash } \\
(\mathrm{Kg})\end{array}$} & \multicolumn{2}{|c|}{$\begin{array}{c}\text { Coarse } \\
\text { Aggregate }\end{array}$} & \multirow{2}{*}{$\begin{array}{c}\text { Fine } \\
\text { Aggregate }\end{array}$} & \multirow{2}{*}{$\begin{array}{l}\mathrm{NaOH} \\
\text { Mass (Kg) }\end{array}$} & \multirow{2}{*}{$\begin{array}{l}\mathrm{Na}_{2} \mathrm{SiO}_{3} \\
(\mathrm{Kg})\end{array}$} & \multirow[t]{2}{*}{ Water } & \multirow{2}{*}{$\begin{array}{c}\text { Super plasticizer } \\
\text { (\%of Fly Ash by } \\
\text { mass) }\end{array}$} \\
\hline & & & $\begin{array}{l}\text { Fr-I } \\
(\mathrm{Kg})\end{array}$ & $\begin{array}{l}\text { Fr-II } \\
(\mathrm{Kg})\end{array}$ & & & & & \\
\hline 1 & $8 \mathrm{M}$ & 427 & 766.08 & 510.72 & 547.20 & 11.07 & 46.93 & 91 & 0 \\
\hline 2 & $10 \mathrm{M}$ & 427 & 766.08 & 510.72 & 547.20 & 13.37 & 46.93 & 88.7 & 0 \\
\hline 3 & $12 \mathrm{M}$ & 427 & 766.08 & 510.72 & 547.20 & 15.37 & 46.93 & 86.7 & 0 \\
\hline 4 & $14 \mathrm{M}$ & 427 & 766.08 & 510.72 & 547.20 & 17.20 & 46.93 & 84.8 & 0 \\
\hline 5 & $16 \mathrm{M}$ & 427 & 766.08 & 510.72 & 547.20 & 18.90 & 46.93 & 83.2 & 0 \\
\hline 6 & $14 \mathrm{M}$ & 427 & 766.08 & 510.72 & 547.20 & 17.20 & 46.93 & 84.8 & $\begin{array}{c}1.5 \\
\text { polycarboxylic base }\end{array}$ \\
\hline 7 & $14 \mathrm{M}$ & 427 & 766.08 & 510.72 & 547.20 & 17.20 & 46.93 & 84.8 & $\begin{array}{c}1.0 \\
\text { Naphthalene } \\
\text { Sulphonate base }\end{array}$ \\
\hline 8 & $14 \mathrm{M}$ & 427 & 766.08 & 510.72 & 547.20 & 17.20 & 46.93 & 84.8 & $\begin{array}{c}1.5 \\
\text { Naphthalene } \\
\text { Sulphonate base }\end{array}$ \\
\hline 9 & $14 \mathrm{M}$ & 427 & 766.08 & 510.72 & 547.20 & 17.20 & 46.93 & 84.8 & $\begin{array}{c}2.0 \\
\text { Naphthalene } \\
\text { Sulphonate base }\end{array}$ \\
\hline
\end{tabular}

Table 4.1 Variation of Compressive Strength with Molarity at Different Temperatures

\begin{tabular}{|c|c|c|c|c|c|}
\hline $\begin{array}{c}\text { Molarity } \rightarrow \\
\text { Temperature } \downarrow\end{array}$ & $8 \mathrm{M}$ & $10 \mathrm{M}$ & $12 \mathrm{M}$ & $14 \mathrm{M}$ & $16 \mathrm{M}$ \\
\hline $40^{\circ} \mathrm{C}$ & $\begin{array}{c}27 \\
\mathrm{MPa}\end{array}$ & $\begin{array}{c}30 \\
\mathrm{MPa}\end{array}$ & $\begin{array}{c}34 \\
\mathrm{MPa}\end{array}$ & $\begin{array}{c}37 \\
\mathrm{MPa}\end{array}$ & $\begin{array}{c}32 \\
\mathrm{MPa}\end{array}$ \\
\hline $60^{\circ} \mathrm{C}$ & $\begin{array}{c}34 \\
\mathrm{MPa}\end{array}$ & $\begin{array}{c}37 \\
\mathrm{MPa}\end{array}$ & $\begin{array}{c}41 \\
\mathrm{MPa}\end{array}$ & $\begin{array}{c}45 \\
\mathrm{MPa}\end{array}$ & $\begin{array}{c}39 \\
\mathrm{MPa}\end{array}$ \\
\hline $80^{\circ} \mathrm{C}$ & $\begin{array}{c}38 \\
\mathrm{MPa}\end{array}$ & $\begin{array}{c}42 \\
\mathrm{MPa}\end{array}$ & $\begin{array}{c}46 \\
\mathrm{MPa}\end{array}$ & $\begin{array}{c}51 \\
\mathrm{MPa}\end{array}$ & $\begin{array}{c}44 \\
\mathrm{MPa}\end{array}$ \\
\hline $100^{\circ} \mathrm{C}$ & 40 & 44 & 48 & 52 & 46 \\
& $\mathrm{MPa}$ & $\mathrm{MPa}$ & $\mathrm{MPa}$ & $\mathrm{MPa}$ & $\mathrm{MPa}$ \\
\hline
\end{tabular}

Table 4.2 Variation of Compressive Strength with Delay time For $14 \mathrm{M}$ Mix at $80^{\circ} \mathrm{C}$

\begin{tabular}{|c|c|}
\hline Delay Time(Hours) & Compressive Strength (MPa) \\
\hline 0 & 51 \\
\hline 24 & 52.5 \\
\hline 48 & 54 \\
\hline 72 & 55 \\
\hline
\end{tabular}

Table 4.3 Effect of Super Plasticizer on Slump and Compressive Strength

\begin{tabular}{|c|c|c|c|c|}
\hline Mix. No. & Molarity & $\begin{array}{c}\text { Superplasticizer } \\
\text { (\% of fly ash by mass) }\end{array}$ & $\begin{array}{c}\text { Slump value } \\
\text { In mm }\end{array}$ & $\begin{array}{c}\text { Compressive } \\
\text { strength in MPa }\end{array}$ \\
\hline 5 & 14 & 0 & 23 & 51 \\
\hline 7 & 14 & 1 & 72 & 50.6 \\
\hline 8 & 14 & 1.5 & 110 & 49.8 \\
\hline 9 & 14 & 2 & 180 & 50.2 \\
\hline
\end{tabular}

Table 4.4 Tensile strength and Modulus of Elasticity For 14M Mix

\begin{tabular}{|c|c|c|c|}
\hline $\begin{array}{c}\text { Rest period } \\
\text { (Hours) }\end{array}$ & Mean Compressive Strength(MPa) & $\begin{array}{c}\text { Indirect Tensile } \\
\text { Strength(MPa) }\end{array}$ & $\begin{array}{c}\text { Modulus of } \\
\text { Elasticity(GPa) }\end{array}$ \\
\hline 0 & 51.0 & 4.99 & 35.71 \\
\hline 24 & 52.5 & 5.07 & 36.23 \\
\hline 48 & 54.0 & 5.14 & 36.74 \\
\hline 72 & 55.0 & 5.19 & 37.08 \\
\hline
\end{tabular}


FIGURE 4.1 VARIATION OF COMPRESSIVE STRENGTH WITH TEMPERATURE AT DIFFERENT MOLARITY

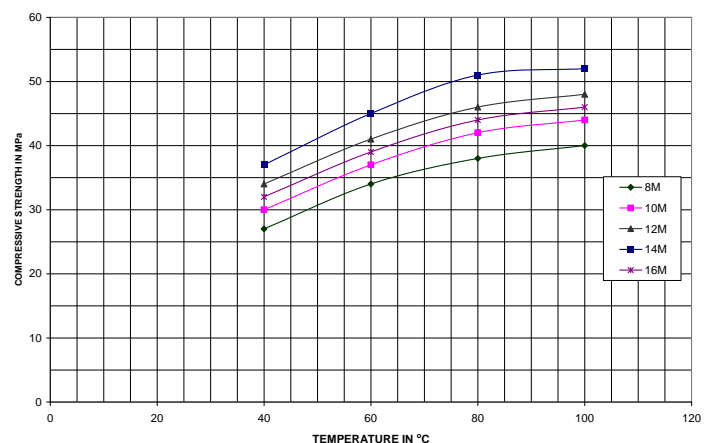

FIGURE4.2 VARIATION OF COMPRESSIVE STRENGTH WITH MOLARITY AT DIFFERENT TEMPERATURE

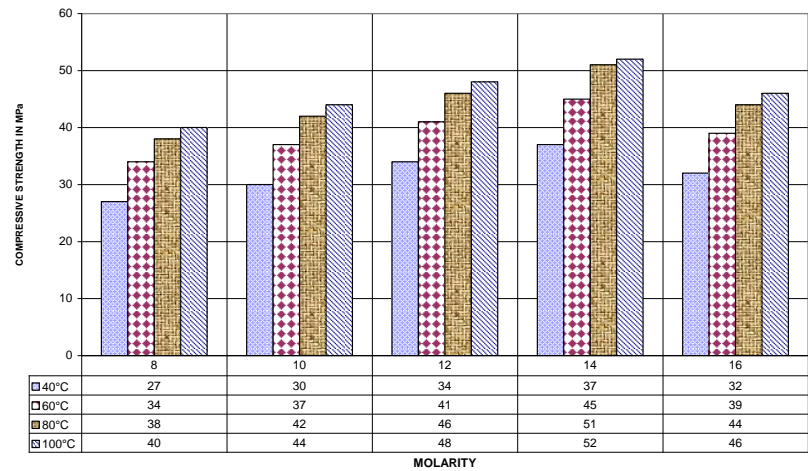

FIGURE 4.3 VARIATION OF COMPRESSIVE STRENGTH WITH DELAY TIME

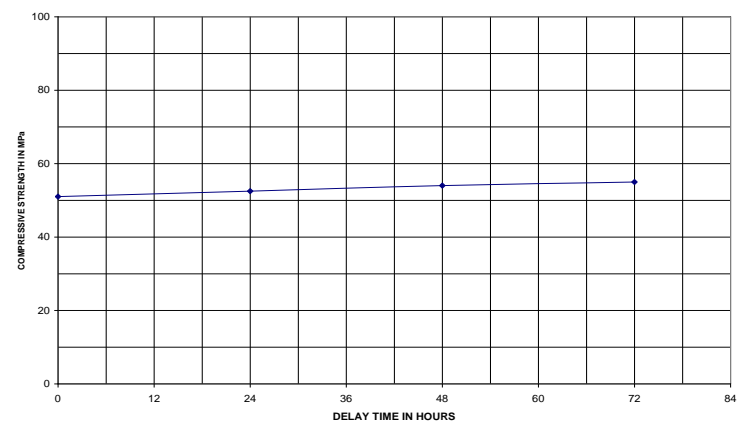

FIGURE 4.4. EFFECT OF SUPER PLASTICIZER ON SLUMP

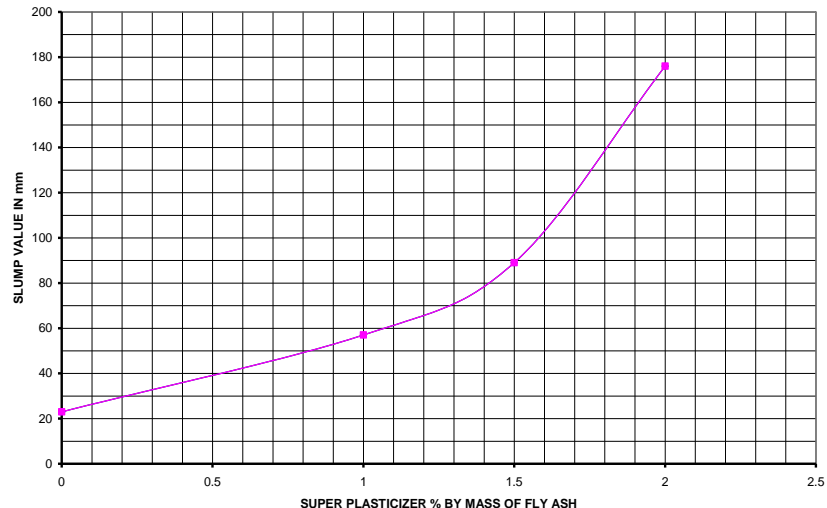




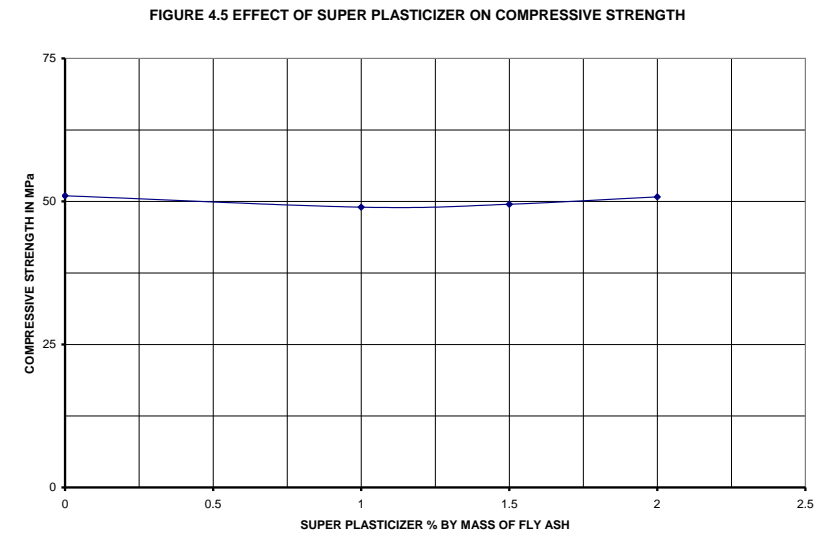

ACKNOWLEDEMENTS

The authors are grateful to Er. Shyam Deo Sharma \& Er. Kumar Mani Bhushan ("BALAJI FLY ASH BRICKS PVT. LTD, JEHANABAD") for introducing them to the fascinating topic of Geopolymer and for their advice, encouragement and financial support.

We also thankful to Dr. V. Pandey (HOD), all teaching and non teaching staff of civil engineering department BIT Sindri, Dhanbad (Jharkhand). 